\title{
ESTABLISHMEN"' OF REVIEW GROUPS ON U.S. DEPARTMENT OF ENERGY ENVIRONMENTAL RESTORATION AND WASTE MANAGEMENT PROGRAM
}

\author{
Final Report
}

L. Dean Eyman, Ph.D.

Waste Policy Institute

1872 Pratt Drive, Suite 1600

Blacksburg, Virginia 24060-6363

December 1992

\begin{abstract}
NOTICE
This report was prepared as an account of work sponsored by the United States Government. Neither the United States nor the Department of Energy, nor any of their employees, nor any of their contractors, subcontractors, or their employees, makes any warranty, express or implied, or assumes any legal liability or responsibility for the accuracy, completeness, or usefulness of any information, apparatus, product or process disclosed or represents that its use would not infringe privately-owned rights.
\end{abstract}

Prepared for

U.S. Department of Energy Grant DE-FG07-89DP48075 


\title{
ESTABLISHMENT OF REVIEW GROUPS ON U.S. DEPARTMENT OF ENERGY ENVIRONMENTAL RESTORATION AND WASTE MANAGEMENT PROGRAM
}

\author{
Final Report
}

\author{
L. Dean Eyman, Ph.D. \\ Waste Policy Institute \\ 1872 Pratt Drive, Suite 1600 \\ Blacksburg, Virginia 24060-6363
}

December 1992

\begin{abstract}
NOTICE
This report was prepared as an account of work sponsored by the United States Government. Neither the United States nor the Department of Energy, nor any of their employees, nor any of their contractors, subcontractors, or their employees, makes any warranty, express or implied, or assumes any legal liability or responsibility for the accuracy, completeness, or usefulness of any information, apparatus, product or process disclosed or represents that its use would not infringe privately-owned rights.
\end{abstract}

Prepared for

U.S. Department of Energy Grant DE-FG07-89DP48075

\section{MASTER}


TABLE OF CONTENTS

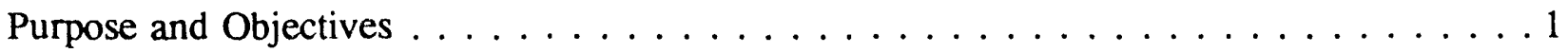

Environmental Management Research Group Research Task . . . . . . . . . . . . . 2

Institutional Review Group for the Environmental Restoration

and Waste Management Five-Year Plan Research Task . . . . . . . . . . . . . 2

Interagency Communication and Technology Exchange Research

Group Research Task . . . . . . . . . . . . . . . . . . . 4

Education Research Group Research Task . . . . . . . . . . . . . . . 4

Technical Peer Review Research Task $\ldots \ldots \ldots \ldots \ldots \ldots$

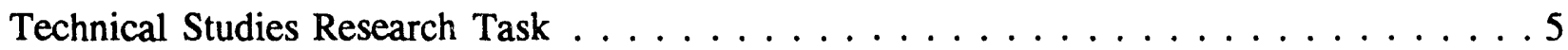

\section{Attachments}

1 Facilitating Public Participation Meetings: Lessons Learned From the Field

2 Public Strategic Management Needs Effective Stakeholder Involvement

3 Report on SEAB Survey Focus Group Sessions

4 A Proposed Office of Technology Development Education Research Group, the Report of the Science and Engineering Education Research Group

5 Implementation Status of the DOE Office of Technology Development Strategic Program Plan for Environmental Education and Development

6 Peer Review and the Contract Between Science and Society

7 Program Flowcharts as a Decisionmaking Aid in Superfund Site Cleanup

8 Development and Use of Innovative Approaches to Waste Management and Environmental Restoration: Potential Liability and Its Implications

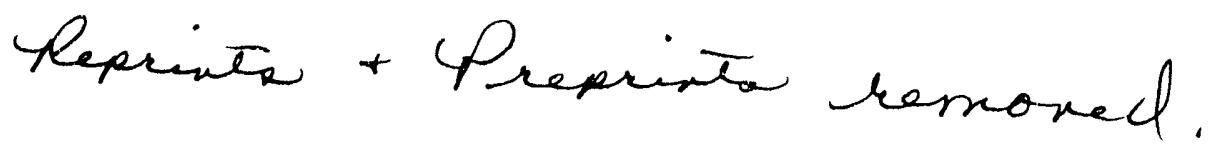




\title{
Final Report
}

\section{U.S. Department of Energy Grant DE-FG07-89DP48075}

\author{
Waste Policy Institute \\ 1872 Pratt Drive, Suite 1600 \\ Blacksburg, Virginia 24060-6363
}

(703) 231-3324

\section{Purpose and Objectives}

A primary purpose of this grant was the establishment of expert research review groups to help facilitate expanded and improved communications and information among states, public, federal agencies, contractors, and DOE, relative to national environmental and waste management issues/problems.

The general objectives of this grant were:

- Research on the further participation avenues of industry and academia and provide appropriate research dicumentation concerning the implementation of multi-party agreements.

- Analysis of the impediments that delay the accomplishment of agreements between states and the federal government for environmental compliance, as well as an assessment of the public need for research because of the above agreements.

- Analysis of the impact of environmental actions on states, industry, academia, public and other federal agencies.

- Provide research to help facilitate an interactive system that provides the various involved parties the capability and capacity to strengthen their commitment to national environmental and waste management goals and objectives.

- Furthering research of public education in the environmental arena and research of needed national education resources in scientific and technical areas related to environmental restoration and waste management. 


\section{Environmental Management Research Group Research Task}

Consisting of participants from public agencies, academia, environmental interest groups, and private industry, the Environmental Management Research Group (EMRG) met in May 1990 to access a broad range of nationally related waste management issues. EMRG members were provided programmatic and technical information from three divisions of DOE's EM organization. EMRG also reviewed environmental management data provided by the EPA and Department of Defense and its application to state, public, and other federal environmental and waste management needs.

Institutional Review Group for the Environmental Restoration and Waste Management Five-Year Plan Research Task

State and Tribal Government Working Group (STGWG) was formed to allo.v state and tribal participation in the Department of Energy's (DOE) annual Environmental Restoration and Waste Management (EM) Five-Year Plan process. STGWG participation includes the following states, tribal governments, and national associations: California, Colorado, Florida, Idaho, Illinois, Kentucky, Missouri, Nevada, New Mexico, New York, Ohio, Oregon, South Carolina, Tennessee, Texas, Washington, the Shoshone-Bannock Tribe, the Umatilla Nation, the Yakima Indian Tribe, the National Governors' Association, the National Association of Attorneys General, and the National Conference of State Legislatures. During the course of this task the Waste Policy Institute (WPI), with the involvement of subgrantee Virginia Polytechnic Institute and State University's (Virginia Tech) Management Systems Laboratories, conducted applied research in public and institutional involvement and facilitated state and tribal participation in STGWG.

Applied research was conducted gaining the perspectives of states, tribes, and representatives of elected officials. The results of this research were applied at eleven different STGWG meetings during the course of the three-year grant period. Research activities included facilitation methodologies to permit improved involvement in public planning, issue resolution meeting techniques, and pre-meeting communications/information necessary for informed meeting participation. Similar research activities were also conducted in conjunction with two Stakeholders' Forum meetings (which included members from STGWG and a broader number of public participants).

Relevant research was also conducted and documented on a more general nature related to public and institutional involvement. Research was conducted from observation and participation in various public involvement forums, including STGWG. Results have been documented in two papers:

Facilitating Public Participation Meetings: Lessons Learned From the Field (Attachment 1) 
Public Strategic Management Needs Effective Stakeholder Involvement (Attachment 2)

Also conducted under this task WPI teamed with the Virginia Tech Survey Research Center and Washington State University to carry out a national public opinion research poll about trust and confidence in the Department of Energy. The survey added substantially to the growing body of research about public trust and confidence. No national information about trust and confidence had previously been available and this survey produced the following major benefits.

Increasing the knowledge about factors that create public trust and confidence in an organization--the factors identified in this survey provide units of measurement for trust and confidence. The findings of this research can and should be used as a model for any public organization looking for a way to measure trust and confidence.

Providing a baseline for future measurements of the public's trust and confidence in Federal agencies' abilities to meet and maintain compliance with environmental regulations using the Department of Energy as a prototype Federal agency. These survey results will be made available to the public and will be useful to the many different individuals and organizations interested or involved in environmental activities. Future surveys will show whether trust and confidence has improved or deteriorated.

WPI, working with the Virginia Tech Center for Survey Research, was responsible for the following activities.

Organizing and leading focus group discussions for the draft survey instruments. A team from WPI, the Virginia Tech Center for Survey Research, and Washington State University developed a series of questions to be discussed at two focus group sessions held on July 29, 1992 and July 30. The objective of the sessions was to explore concepts related to public trust at a very early stage of instrument development to help formulate specific questions and response categories for the survey. This exercise generated many of the factors that are used to measure trust and confidence. A technical report entitled Report on SEAB Survey Focus Group Sessions was prepared following focus group meetings (Attachment 3).

Facilitating review of the survey. WPI arranged to have five survey research experts review and comment on the draft survey instruments.

Compiling the sample frames for the two surveys. Contacts from 950 external organizations were gathered from community relations mailing lists and lists of commentors from planning documents. 
Developing the sample methodology. WPI also worked with the Virginia Tech Survey Research Center to develop the correct sampling methodology. Because of the national implications of the survey, the population to be sampled from was as complete as possible and sampling was as close to random as possible.

\section{Interagency Communication and Technology Exchange Research Group Research Task}

Research for interagency collaboration was conducted through participation in an interagency Federal Working Group focusing on a cooperative approach to development of technical solutions to environmental restoration and waste management problems shared by States, commercial entities, and the Federal government. In an effort to provide public assistance, WPI facilitated the involvement of the U.S. Departments of Defense, Interior, Energy, and the Environmental Protection Agency with the Western Governors' Association. Efforts by the Federal Working Group resulted in conclusions that the participating agencies share common problems, will benefit from better communications and cooperation with each other (and the public), and that successful deployment of emerging technologies must first overcome institutional and regulatory barriers.

\section{Education Research Groups Research Task}

WPI established and convened groups to research federal agency support of national public (K12) and higher education. The products of these groups were used by WPI researchers with relevant information provided to affected parties.

WPI formed an Education Development Group titled the Task Force on Education (TFE) to research ways to enhance the overall effectiveness of national environmental education activities. The major output of this group was the creation of a framework for national environmental education initiatives in October 1990. The ideas and emphases from this framework were used by WPI researchers.

The Science and Engineering Education Research Group (SEER) was established by WPI and convened three times. The research of this working group of expert educators provided independent, credible, and objective identification, analysis, and review of major science, math and engineering education issues. SEER submitted a research report entitled $A$ Proposed Office of Technology Development Education Research Group, the Report of the Science and Engineering Education Research Group (Attachment 4).

The Manpower Research Group (MRG) was convened by WPI and included representatives from the National Research Council's Office of Scientific and Engineering Personnel, the Commission on Professionals in Science and Technology, the Bureau of Labor Statistics, the Hazardous Waste Action Coalition, and the EPA Office of Human Resource Management. The original charge, which was fulfilled, was to research an action plan to establish a manpower assessment 
process to address state, federal, and public related environmental and waste management problems. The MRG has met twice (February 5 and 11, 1991), to (1) develop and reach consensus on the elements of an action plan for assessing manpower demand and supply both nationally and regionally, and for determining the ability of regional education/training pipelines to meet regional demand; (2) research and identify elements needed to cooperate in designing the assessment instruments; and (3) research and identify the appropriate process for achieving the needed cooperation of state, federal, and public represented organizations.

Additionally, WPI researchers participated and contributed research on nationwide environmental education strategies. Research resulted in presentation and publication of a paper entitled Implementation Status of the DOE Office of Technology Development Strategic Program Plan for Environmental Education and Development, presented at the Symposium on Waste Management in Tucson, Arizona March 1-5, 1992 (Attachment 5).

\section{Technical Peer Review Research Task}

Technical peer review is used to provide independent, objective, external, peer review of research and development. Based on research of available literature, and a survey of primary Federal agencies using technical peer review, a paper entitled Peer Review and the Contract Between Science and Society (in press) was prepared and has been accepted for publication in The Environmental Professional, Journal of the National Association of Environmental Professionals (Attachment 6).

\section{Technical Studies Research Task}

Research under this task resulted in two research reports.

1. Presentation and publication of a paper entitled, Program Flowcharts as a DecisionMaking Aid in Superfund Site Cleanup, presented at the Sixth Annual Hazardous Waste Technology Conference in Manhattan, Kansas, during May 29-30, 1991 (Attachment 7).

2. A research project was conducted to assist with the identification and analysis of liability issues relevant to the development, testing, and use of innovative approaches to environmental restoration and waste management. The subsequent research report entitled Development and Use of Innovative Approaches to Waste Management and Environmental Restoration: Potential Liability and Its Implications was prepared (Attachment 8). The report addressed a number of legal issues, provided information on establishing policies and programs to further efforts to stimulate the development and use of innovative approaches. Legal terminology in the text was kept to a minimum but legal and literature citations were included to allow readers to obtain further information. 

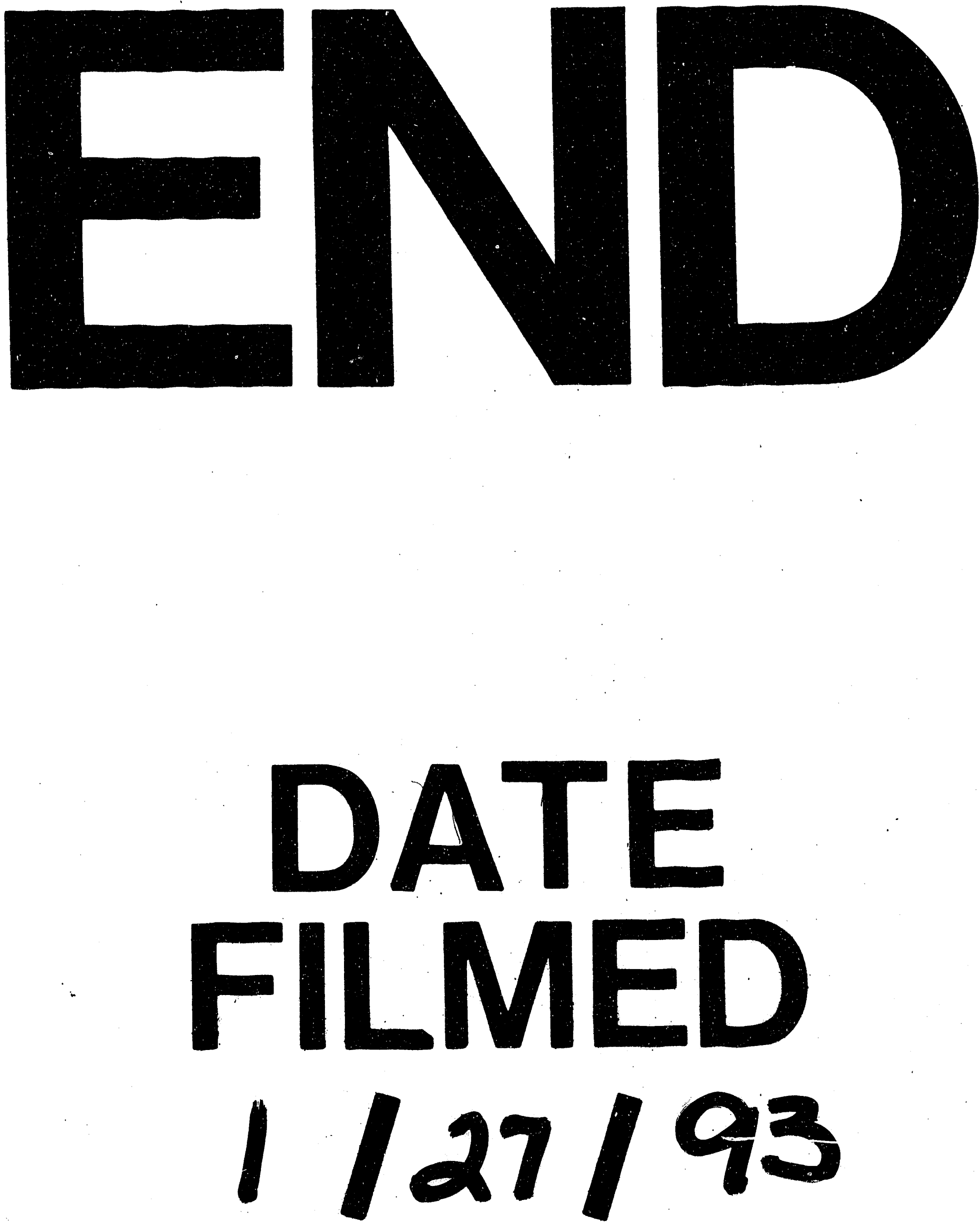
